\title{
Oral Manifestations of Drug Abuse: A Review of Literature
}

\author{
Lídia Audrey Rocha Valadas ${ }^{1, *}$, Mariana Lima Fernandes ${ }^{2,3}$, Maria Izabel G. Silva², Maria do Carmo de Oliveira Citó ${ }^{2}$, Iris Cristina Maia \\ Oliveira ${ }^{2,4}$, Marília Leite Dias ${ }^{2}$, Ana Cristina de Mello Fiallos ${ }^{1}$, Leonardo Freire Vasconcelos ${ }^{2,5}$, Luciana Kelly Ximenes dos Santos ${ }^{2}$, Alyne \\ Mara Rodrigues de Carvalho ${ }^{2,5}$, Francineudo Oliveira Chagas ${ }^{1}$, Francisca Cléa Florenço de Sousa ${ }^{2}$ \\ 'Pharmacy, Dentistry and Nursing School, Federal University of Ceara, Fortaleza, CE, BRAZIL. \\ ${ }^{2}$ Medicine School, Federal University of Ceara, Fortaleza, CE, BRAZIL. \\ 3Physiotherapy School, UniChristus, CE, BRAZIL. \\ ${ }^{4}$ Nursing School, Rodolfo Teófilo Faculty, Fortaleza, CE, BRAZIL. \\ ${ }^{5}$ Pharmacy School, Mauricio de Nassau University Center, Fortaleza, CE, BRAZIL.
}

\begin{abstract}
The use of psychoactive substances is an ancient fact in human history that has become a public health problem. Recognizing the severity of oral problems related to drug abuse and in view of the importance of the contribution of Dentistry in this theme, it became pertinent to perform a literature review on oral manifestations resulting from drug use. A literature review of articles published between 1991 and 2019 was performed, mainly through MEDLINE and LILACS, using as descriptors "oral manifestations", "drugs of abuse", "oral disorders". We selected 41 articles related to the theme. There was a high prevalence of oral lesions among drug users in relation to the general population. Among the most frequent oral manifestations are caries, periodontitis, xerostomia, leukoplakia. The abuse of drugs can cause the most diverse damages to the oral health. Dental surgeons,
\end{abstract}

when aware of the oral manifestation / drug abuse relationship, can play an active role in identifying and treating drug addicts.

Key words: Oral manifestations, Drugs of abuse, Dentistry, Drugs, Oral diseases.

Correspondence

Lidia Audrey Rocha Valadas

1210 Capitao Francisco Pedro, Federal University of Ceara, Fortaleza, BRAZIL.

Phone: +5585336600

Email: lidiavaladas@gmail.com

DOI: 10.5530/jyp.2020.12.3

\section{INTRODUCTION}

The use of psychoactive substances is an old fact in the history of mankind that, over time, has become a public health problem with serious personal and social consequences. ${ }^{1}$ Drug use is estimated to reach about 27 million. $0.6 \%$ of the world's population and who are involved in 1 in 100 adult deaths worldwide. ${ }^{2}$ According to Arroyo-Fernandez ${ }^{3}$ the World Health Organization (WHO) defines the definition of drugs as all therapeutic substances or not, introduced into the body by any mechanism, capable of acting on the central nervous system (CNS) of the individual and capable of causing a physical or intellectual alteration, the experimentation of new sensations or the modification of his psychic state. The analysis of statistical studies has suggested a significant increase in drug-dependent individuals as well as the lack of depth in this subject by Dentistry. ${ }^{4}$ It is noted the need for the dental surgeon to be aware during the care of these patients, ${ }^{5}$ considering that in many cases, professionals in this area will be the first to have the opportunity to diagnose the appearance of possible changes arising from the consumption of cigarettes, alcohol or illicit drugs. ${ }^{4}$

When compared to the general population, drug users have a high prevalence of oral lesions. ${ }^{5}$ A study in Portugal found that $20 \%$ of patients over the age of 18 who sought the public dental service were drug abusers or psychotropic users and most of them were unaware of the relationship between drug use and the presence of oral manifestations. ${ }^{6}$ Colodel et al. ${ }^{7}$ conducted a study about the oral alterations observed in users of different types of drugs. There was a high prevalence of dental caries and periodontal disease in the target population, as well as the presence of soft tissue changes, thus reaffirming the relevance of studies related to oral clinical manifestations in drug users (Table 1).
The aim of the present study was to perform a literature review about the classification of drugs of abuse, the main oral manifestations observed and the relationship with oral cancer.

\section{MATERIALS AND METHODS}

To this study, a literature review of the articles published between 1991 and 2019 was carried out, mainly through the PUBMED and LILACS databases. Thus, articles from systematic reviews, epidemiological studies and case reports were selected in portuguese and english languages. We selected 41 articles related to the theme in question.

\section{LITERATURE REVIEW}

\section{Drug abuse classification}

Substances with potential for abuse come from a variety of sources and may be of natural, semi-synthetic or synthetic origin. Those considered natural, such as cannabinoids, are taken directly from nature, while semi-synthetic ones are obtained by structural modification of natural substances (eg. heroin) and synthetic ones, in turn, are related to natural drugs, but being obtained by laboratory synthesis, such as methadone. ${ }^{8}$ Another classification system rearranges these substances according to their central effects, allocating them as depressants, stimulants or hallucinogens. Depressive drugs decrease brain activity, often in a dose-dependent manner, initially triggering a sedative effect. Stimulants increase in central activity, whereas hallucinogens exert a distorting effect on sensory experiences and are not characterized by accelerating or slowing down central nerve activity. ${ }^{9}$ 


\section{Alcohol}

Alcohol consumption is the largest public health problem in Brazil and is largely responsible for the country's mortality, ${ }^{10}$ yet its legal status makes it socially accepted and widely consumed. ${ }^{11}$ Alcohol misuse has both deleterious effects for systemic health, as for oral health. In this case, the high consumption is related to the increased risk for periodontal diseases, as well as the manifestation of adverse effects during the treatment of these diseases. In addition, alcoholics often neglect oral hygiene, which favors the formation of periodontopathogenic biofilm, exacerbating the inflammatory response by increasing the amount of cytokines. ${ }^{12}$

Periodontal changes related to alcohol abuse include ulcer-necrotizing gingivitis, periodontitis, gingival recession and a greater amount of bone loss. Alcohol intake is also known to cause changes in saliva, causing decreased salivary flow. ${ }^{12}$ Because saliva has protective properties, reduced flow makes the mouth more susceptible to injuries such as caries and periodontitis. Morphological changes may be observed, such as accumulation of adipose tissue, duct hyperplasia, reduction of the proportion of acinar cells and reduction of immunoglobulin levels present in saliva. ${ }^{13}$ The risk that alcohol offers to induce oral cancer still generates considerable controversy, however, it is known to possess the ability to irritate the oral mucosa epithelium and stimulate cell proliferation. ${ }^{14}$ A study in Spain showed that patients who developed oral cancer drank distillates frequently. ${ }^{15}$

It should be remembered that mouth examination is often of fundamental importance for the early diagnosis of oral cancer in alcoholic patients. Patient orientation and appropriate referral to other health professionals will certainly positively interfere with the evolutionary aspect of oral cancer. $^{12}$

\section{Hallucinogens - Mushrooms and LSD}

According to the current literature, there are records of more than 200 mushroom species with hallucinogenic potential. Species belonging to the genera Psilocybe, Panaeolus and Plusteus are commonly found in Brazil, marked by the presence of indolic alkaloids, especially psilocybin and psilocin. ${ }^{16}$ As well as psilocin and psilocybin, LSD (lysergic acid di- ethylamide), a product of Metabolism of the fungus Claviceps purpurea also belongs to the class of hallucinogens indolalkylaminase with indistinguishable effects. ${ }^{7}$

In Europe and the United States, for example, there is a high prevalence of hallucinogenic mushroom use among young adults. ${ }^{17,18}$ It is known that in Brazil the consumption of these substances is not significant. Research on the possible oral manifestations caused by the use of LSD and mushrooms resulted in only one finding, Souza's work, ${ }^{19}$ which briefly relates the use of hallucinogens to orofacial damage such as bruxism and trismus. ${ }^{6,19}$

\section{Amphetamines}

Methamphetamine is a powerful, highly addictive stimulant that affects multiple systemic organs, increasing physical activity and wakefulness and producing other effects including cardiac arrhythmias, hypertension, hallucinations and violent behavior. ${ }^{20}$ Methamphetamine has been linked to various oral problems. Dental patients who abuse methamphetamine may have poor oral hygiene, reduced salivary flow, xerostomia, rampant caries and excessive tooth wear. In a study conducted in California, it was found that methamphetamine users had a higher number of dental diseases and reported more dental problems than non-users, thus establishing the influence of the drug on oral health..$^{20,21}$ Dental treatment of users of methamphetamine users can be challenging, requiring a thorough medical history and careful oral examination, but the most important factor in treating oral effects is to get the patient to stop using the drug. Therefore, dental surgeons need to be aware of the oral manifestations and the medical risks posed by these patients. ${ }^{20}$

\section{Cannabinoids}

The prevalence of marijuana use is outnumbered only by alcohol and tobacco and is the most widely used illicit drug in the world. ${ }^{22}$ Some studies suggest that society generally pays less attention to the damage caused by marijuana because of its ill effects as obvious as other drugs. However, in recent years, research has begun to invest in evaluating the extent of the effects of the use of this drug. ${ }^{23}$

Table 1: Drugs of abuse and their main oral manifestations.

\begin{tabular}{|c|c|}
\hline DRUG ABUSE & MAIN ORAL MANIFESTATIONS \\
\hline Alcohol & $\begin{array}{c}\text { Dental Caries; Necrotizing ulcerative gingivitis; Periodontitis; Gingival recession; Decreased } \\
\text { salivary flow. }{ }^{5,12,13}\end{array}$ \\
\hline Hallucinogens & Orofacial damage; Bruxism; Trism..$^{6,19}$ \\
\hline Amphetamines & Decreased salivary flow; Xerostomia; Rampant caries; Excessive tooth wear. ${ }^{20,40}$ \\
\hline Cannabinoids & $\begin{array}{c}\text { Caries; Periodontitis; Cannabic stomatitis; Sialostasis; Xerostomia; Leukoplakia; Increased } \\
\text { bacterial plaque; Moderate and severe gingivitis; Candidosis; Oral papilloma; Risk of } \\
\text { development of oral cancer. }{ }^{6,19,24}\end{array}$ \\
\hline Cocaine and derivatives & $\begin{array}{c}\text { Palatal perforations; Irritation and dryness of the oral mucosa; Acute pain; Acute necrotizing } \\
\text { ulcerative gingivitis (GUN); Periodontitis; Gingival laceration; Atypical white lesions on the } \\
\text { gums; Dental abrasion and erosion; Bruxism; TMJ pain; Morning headaches; Glossodynia; } \\
\text { Angular cheilitis. }{ }^{26-29}\end{array}$ \\
\hline Ecstasy & $\begin{array}{l}\text { Xerostomia; Caries; Tooth erosion; Bruxism; Trismus; Bite of lips and tongue; Tremor of the face; } \\
\text { Nystagmus; Abfraction injuries; Dentin sensitivity; tooth mobility; Support bone resorption; } \\
\text { Gingival necrosis; Oral ulcers; Paraesthesias; Alteration of phonation; Jaw edema. }{ }^{6.35,36}\end{array}$ \\
\hline Nicotine & $\begin{array}{l}\text { Periodontitis; Leukoplakia; Leukoedema; Necrotizing ulcerative gingivitis; Oral cancer; Oral } \\
\text { cancer. } \text {, }^{6,3,38}\end{array}$ \\
\hline Opioids & $\begin{array}{l}\text { Atypical caries; Bruxism; Dental calculus; Necrotizing ulcerative gingivitis; Periodontitis; } \\
\text { Xerostomia; Herpes simplex; Oral papilloma; Candidiasis; Leukoplakia; Oral carcinoma. }{ }^{6,19}\end{array}$ \\
\hline
\end{tabular}


Cannabis users generally have poorer oral health than non-users, with an increased risk of tooth decay and periodontal disease. Marijuana smoke has a carcinogenic potential and is associated with dysplastic changes and potentially malignant lesions in the oral mucosa such as leukoplakia and erythroplasia. ${ }^{24}$ Among the main manifestations related to cannabinoid use is cannabic stomatitis, which is an inflammation characterized by presenting oral mucosa leukoedema and hyperkeratosis; ${ }^{24}$ sialostasis; xerostomia, with consequent increased risk of caries; leukoplakia; high rate of missing, filled and decayed teeth (DMFT); Increased bacterial plaque; moderate and severe gingivitis; alveolar bone loss; candida and possible appearance of oral papilloma. ${ }^{6,19}$

A synergistic effect between tobacco and cannabis smoke has been observed, suggesting that their risk interactions further increase their risk of developing oral cancer. ${ }^{24}$ Cannabis may also have variable effects on the Parasympathetic Nervous System, which, in combination with a stress response, such as a visit to the dentist and the use of epinephrinecontaining local anesthetic solutions may prolong the tachycardia already induced by substance use. Therefore, oral health care professionals should be aware of the various adverse effects of cannabis on patients' systemic and oral health and be aware of drug abuse and their medical history. ${ }^{24}$

\section{Cocaine and derivatives}

Cocaine is a natural substance extracted from the leaves of a plant that occurs exclusively in South America: Erythroxylon coca. ${ }^{25}$ Cocaine abuse has increased in recent decades and as a result there has been an increase in reports of midpalatal perforations. ${ }^{26}$ In addition, drug abuse has increased reports of cardiovascular disease, neurological, respiratory and gastrointestinal complications and orofacial destructive lesions. ${ }^{27}$

The vasoconstrictor effect caused by cocaine use may produce direct irritation and nasal and palatal mucosal ischemia, causing long-term oronasal perforation secondary to maxillary bone destruction. As a result, a number of changes in different locations of the respiratory and gastrointestinal mucosa have been reported, such as irritation and dryness of the oral and nasal mucosa, destruction of the nasal septum and nasal fossa sidewalls and, less frequently perforation, line middle or palate destruction. ${ }^{21,28-32}$

Cocaine and its derivatives, such as crack or oxide, present as major oral manifestations acute pain, severe gingivitis and may progress to periodontitis with exaggerated gingival retraction, sometimes evolving to acute necrotizing ulcerative gingivitis (NUG), gingival laceration, atypical white lesions gums (similar to burns), high DMFT index, presence of abrasion and dental erosion lesions, ischemic palate ulceration sometimes with palate perforation and nasal septum, mucosal dysplasia, bruxism, TMJ pain and morning headache; glossodynia, angular cheilitis and candidiasis. ${ }^{6,19,33}$

\section{Ecstasy}

3,4-Methylenedioxymethamphetamine (MDMA, Ecstasy) is a derivative of amphetamine. Its pattern of use is similar to that of other drugs of abuse, but an increase in consumption by young people has been observed. ${ }^{34}$ Although not a new drug, the vast majority of health professionals are unaware of its effects or complications resulting from its use. ${ }^{34}$ According to Brand, Dun, Amerongen ${ }^{35}$ ecstasy causes: xerostomia (48h after consumption), tooth decay, dental erosion, bruxism, trismus, lip and tongue bite, facial tremor, nystagmus, abbreviation lesions referentially to premolars and molars, dentin sensitivity, tooth mobility, support bone resorption, gingival necrosis (gingival fenestration), oral ulcers, paresthesias, alteration of phonation, painful edema of the buccal and labial zone of the jaws and diffuse perioral and intraoral edema (edema on the back of the tongue, bilateral grayish tonsillar region without evi- dence of ulceration or exudate). The severity of oral effects is correlated with the number of doses consumed and their frequency. ${ }^{6,35,36}$

\section{Nicotine}

Nicotine is one of the most widely used licit drugs, especially in the form of cigarettes, as it is the object of intense advertising and produces powerful physical dependence as well as psychological dependence. ${ }^{37}$ It is known that nicotine consumption is related to alveolar bone loss, loss of periodontal insertion, formation of periodontal pockets and consequently loss of dental elements. This is due to the action of nicotine on the immune functions of monocytes and neutrophils in serum IgG reacting against Agregatibacter actinomycetemcomitans ( $\mathrm{Aa}$ ) which is an important oral pathogen. Thus, tobacco smoke has been identified as the main risk factor associated with periodontal disease. ${ }^{38}$

The influence of smoking on the host immune response has revealed that nicotine impairs neutrophil bactericidal activity against oral pathogens by inhibiting the production of superoxides and hydrogen peroxide, which are responsible for bacterial death. ${ }^{38}$ nicotine use are: development of leukoplakia, which among the potentially malignant lesions is the one with the greatest transformation potential for malignant lesions; leukoedema, which is not necessarily an injury, but is more pronounced in smokers than in non-smokers; ${ }^{14}$ acute necrotizing ulcerative gingivitis (NUG), which causes bleeding and fetid odor in the mouth and is directly related to the amount of cigarettes per day; lip cancer and oral cancer. All of these changes are at increased risk when there is a combination of smoking and excessive alcohol consumption. ${ }^{6}$ Among the various factors related to oral cancer, alcoholism and smoking are described as the major contributors to its development. ${ }^{39}$

\section{Opioids}

Opium is obtained from the milky exudate from the incision of immature poppy seed capsules, whose scientific name is Papaver somniferum L. To produce euphoric and analgesic effects, opium is often used in the form of chewing gum or solution. It can also be smoked in special pipes for effect. ${ }^{40}$ Opiate use can cause immune system modulation through central or peripheral mechanisms, which can accelerate the process of periodontal disease and make the individual more susceptible to fungal and viral infections. ${ }^{6}$ Immunomodulatory effects occur not only in drug addicts, but also in patients who use morphine or other opioids for pain relief. ${ }^{41}$

According to Souza, ${ }^{19}$ opiate users may present some oral manifestations, such as: high DMFT, with the presence of atypical caries, bruxism; dental calculus; Gingivitis - which can develop into periodontitis and sometimes chronic ulcerative gingivitis (NUG); xerostomia; herpes simplex, cytomegalovirus, oral papilloma and candidiasis. Tobacco-conjugated heroin use may lead to a higher incidence of leukoplakia and oral carcinoma and methadone use is strongly associated with the onset of rampant caries.

\section{CONCLUSION}

Through the analysis of epidemiological studies on this theme, an increase in the incidence of psychoactive substance abuse cases was observed. This situation requires further improvement by health professionals, so that they can be better able to work with this patient profile. Abuse drugs can cause the most damage to oral health. These problems can range from cavities and periodontitis to more complex diseases such as oral mucosal cancer. Therefore, the need for a larger number of studies to help in the diffusion of this knowledge.

Dentists, when aware of the oral manifestation / drug abuse relationship, can play an active role in identifying and treating drug addicts. This identification can be understood as a gain from the point of view of 
public health, since, having this initial recognition, drug addicts may, in addition to receiving appropriate dental treatment, be referred to other health professionals. Thus, with the help of a multidisciplinary team, they can be treated according to their respective needs.

\section{ACKNOWLEDGEMENT}

We acknowledge the Abuse of Drugs Prevention Program-Federal University of Ceara.

\section{CONFLICT OF INTEREST}

The authors declare no conflict of interest.

\section{ABBREVIATIONS}

Aa: Agregatibacter actinomycetemcomitans; CNS: Central nervous system; DMFT: Missing, filled and decayed teeth; NUG: Necrotizing ulcerative gingivitis; WHO: World Health Organization.

\section{REFERENCES}

1. Marques ACPR, Cruz MS. O adolescente e o uso de drogas. Rev Bras Psiquiatr. 2000;22(2):32-6

2. UNODC-United Nations Office on Drugs and Crime. World Drug Report. United Nations Pub. 2012;12(1).

3. Arroyo-Fernandez A. Medical-legal evaluation of abuse drugs. Med Clin 2006;126(16):632-6

4. Cho CM, Hirsch R, Johnstone S. General and oral health implications of cannabis use. Aust Dental J. 2005;50(2):70-4.

5. Fernandes JP, Brandão VSG, Lima AAS. Prevalência de lesões cancerizáveis bucais em indivíduos portadores de alcoolismo. Rev Bras Cancerol. 2008:54(3):239-44.

6. Lero IMVA. Patologias e terapêuticas que interferem a prática do médico dentista. Monografia (Licenciada em Medicina Dentária) - Faculdade De Ciências da Saúde da Universidade Fernando Pessoa de Porto. 2009;125.

7. Colodel EV, Silva ELFM, Zielak JC, Zaitter W, Michel-Crosato E, Pizzatto E. Alterações bucais presentes em dependentes químicos. RSBO. 2009;6(1):44-8.

8. Martinez FC. Las Drogas: Educacion y Prevencion. Madrid Cultural. 2003.

9. Holmes DS. Dependência e abuso de substância. In: Psicologia dos Transtornos Informe Mundial Sobre las Drogas. $1^{\text {st }}$ ed. 2001.

10. Meloni JN, Laranjeira R. Custo social e de saúde do consumo do álcool. Rev Bras Psiquiatr. 2004;26(1):7-10.

11. Minayo MCS, Deslandes SF. A complexidade das relações entre drogas, álcool e violência. Cad Saúde Públ. 1998;14(1):35-42.

12. Péret ACA, Bonato KB. A participação do dentista na equipe multidisciplinar para o tratamento do paciente alcoolista. Arq Bras Odontol. 2008;4(2):70-5

13. Carrard VC, Mendez M, Nolde J, Alves LD, Fossati ACM, Santanna FM. Influence of ethanol consumption in salivary glands. Scimed. 2007;17(2):87-92.

14. Neville BW, Damm DD, Allem CM, Bouquot JE, Allen CM. Patologia Oral e Maxilofacial. $3^{\text {th }}$ ed., Elsevier. 2009;992.

15. Castellsague X, Quintata MJ, Martinez MC, Nieto A, Sanchez MJ, Juana A. The role of type of tobacco and type of alcoholic beverage in oral carcinogenesis. Int J Cancer. 2004;108(5):741-9.

16. Guzmán G. Species Diversity of the Genus Psilocybe in the Word Mycobiota, with Special Attention to Hallucinogenic Properties. Int J Med Mushrooms.
2005;7(1):305-31.

17. EMCDDA. Annual report on the state of the drugs problem in Europe. Lisbon. 2010.

18. NSDUH. Substance Abuse and Mental Health Services Administration, Results from the 2010 National Survey on Drug Use and Health. Summary of National Findings Series. 2010;11(4658).

19. Souza DV. A Medicina Dentária e o Paciente Toxicodependente. Universidade Fernando Pessoa. 2006.

20. Faucett EA, Marsh KM, Farshad K, Erman AB, Chiu AG. Maxillary sinus manifestations of methamphetamine abuse. Allergy and Rhinology. 2015;6(1):1-6.

21. Shetty V, Mooney LJ, Zigler CM, Belin TR, Murphy D, Rawson R. The Relationship between Methamphetamine use and Increased Dental Disease. J Am Dent Assoc. 2010;141(3):307-18.

22. Almeida PP, Novaes MAFP, Bressanr A, Lacerda ALT. Revisão: Funcionamento executivo e uso de maconha. Rev Bras Psiquiatr. 2008;30(1):69-76.

23. Jungerman FS, Laranjeira R, Bressan RA. Maconha: Qual a amplitude de seus prejuízos?. Rev Bras Psiquiatr. 2005;27(1):5-6.

24. Spezzia S. Repercussões bucais do uso de drogas na adolescência. Revista de Ciências Médicas. 2019;27(2):93-100.

25. Marques LAR, Rodrigues NEMR, Lotif MAL, Nunes NAPN, Mororó JM, Lobo PLD. Abuso de drogas e suas consequências na saúde bucal: Uma revisão de literatura. Revista da Faculdade De Odontologia De Lins. 2016;26(1):29-35.

26. Silvestre FJ, Herbera AP, Sandoval AP, Bagán JV. Hard palate perforation in cocaine abusers: A systematic review. Clin Oral Invest. 2010;14(6):621-8.

27. Basile FV, Tournieux TT, Cintra HL. Midline palate perforation secondary to cocaine abuse. J Plast Reconstr Aesthet Surg. 2008;61(5):588-90.

28. Trimarchi M, Nicolai P, Lombardi D, Facchetti F, Morassi ML, Maroldi R, et al. Sinonasal osteocartilaginous necrosis in cocaine abusers: Experience in 25 patients. Am J Rhinol. 2003;17(1):33-43.

29. Yewell J, Haydon R, Archer S, Manaligod JM. Complications of intranasal prescription narcotic abuse. Ann Otol Rhinol Laryngol. 2002;111(2):174-7.

30. Lancaster J, Belloso A, Wilson CA, Mccormick M. Rare case ofnaso-oral fistula withextensiveosteocartilaginous necrosis secondary to cocaine abuse: Review of otorhinolaryngological presentations in cocaine addicts. J Laryngol Otol. 2000;114(8):630-3.

31. Mattson-Gates G, Jabs AD, Hugo NE. Perforation of the hard palate associated with cocaine abuse. Ann Plast Surg. 1991;26(5):466-8.

32. Talbott JF, Gorti GK, Koch RJ. Midfacial osteomyelitis in a chronic cocaine abuser: A case report. Ear Nose Throat J. 2001;80(10):738-43.

33. Rosas MP, Santos CIJ, González CLG. Perforación em bóveda palatina por consumo de cocaína. Med Oral Patol Cir Bucal. 2006;11(3):239-42.

34. Xavier CAC, Lobo PLD, Fonteles MMF, Vasconcelos SMM, Viana GSB, Sousa FCF. Exxtase (MDMA): Efeitos farmacológicos e tóxicos, mecanismo de ação e abordagem clínica. Rev Psiquiatr Clín. 2008;35(3):96-103.

35. Brand HS, Dun SN, Amerongen AVN. Ecstasy (MDMA) and oral health. Br Dent J. 2008;204(2):77-81.

36. Ress TD. Oral Effects of Drug Abuse. Crit Rev Oral Biol Med. 1992;3(3):163-84

37. Katzung BG. Basic and Clinical Pharmacology. 10 $0^{\text {th }}$ ed, Guanabara Koogan. 2010.

38. Camargo GADCG, Abreu MGL, Dos SR, Crespo MA, Wenderoscky LF. Aspectos clínicos, microbiológicos e tratamento periodontal em pacientes fumantes portadores de doença periodontal crônica: Revisão da literatura. Revista Brasileira De Odontologia. 2016;73(4):325.

39. Seyer BA, Grist W, Muller S. Aggresive destructive midfacial lesion from cocaine abuse. Oral Surg Oral Med Oral Pathol Oral Radiol Endod. 2002;94(4):465-70.

40. Seizi O, Camargo MMA, Batistuzzo JAO. Fundamentos de Toxicologia, 3 ed. São Paulo: Atheneu. 2008;474.

41. Mellon RD, Bayer B. Evidence for central opioid receptors in the immunomodulatory effects ofmorphine: Review of potencial mechanism(s) of action. J Neuroimmunol. 1998;83(1-2):19-28

Article History: Submission Date : 30-12-2019; Revised Date : 01-02-2020 ; Acceptance Date : 08-02-2020

Cite this article: Valadas LAR, Fernandes ML, Silva MIG, Citó MCO, Oliveira ICM, Dias ML, et al. Oral Manifestations of Drug Abuse: A Review of Literature. J Young Pharm. 2020;12(1):11-4. 